\title{
人胎盤,今氏銀反應二就 $テ$
}

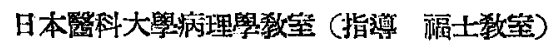

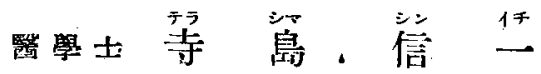

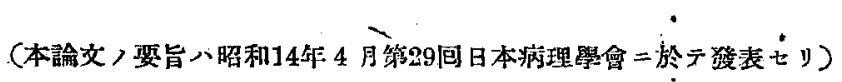

目次

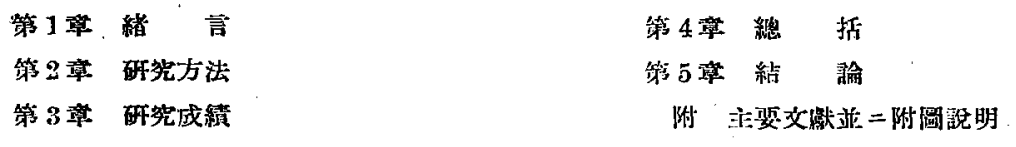

第1章 緒 、亭

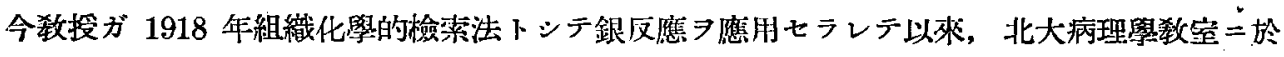
テ之が應胢八各方面二行ハレ，今ヤ殆ンド盡サザルナキ觀アリ。然ル＝胎盤＝關スル銀反應=

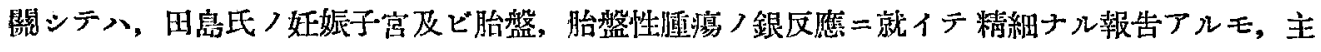

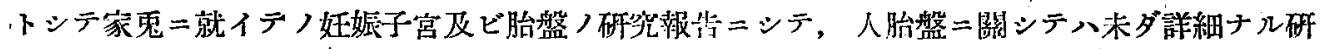
究報告アルタ知ラズ。

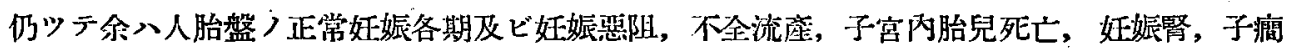

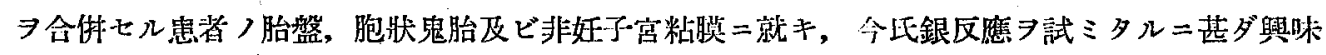

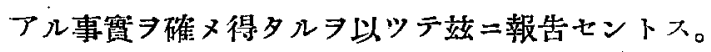

第 2 章 研 究 方 法

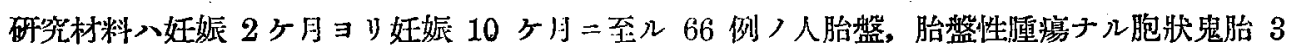

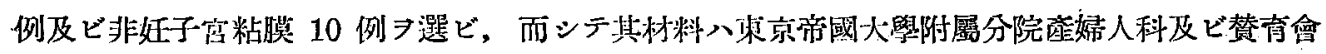
病院產婦人科ニテ獲多儿新鮮ナル組織ヨ材料トス。

研究方法八主トシテ今氏銀反應標準法ニシテ，新焦ナル材料ヨ㧺取シ直チニ今氏銀反應 $\mathrm{A}$ 泟

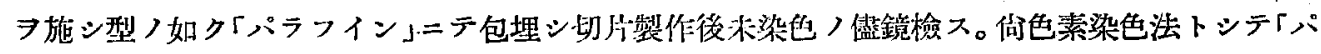
ラフィン」四片ニ「へマトキシリン」染色,「へマトキシリン・エオジン」普速染色ヨ行ヒ寥考二倛 七リ。

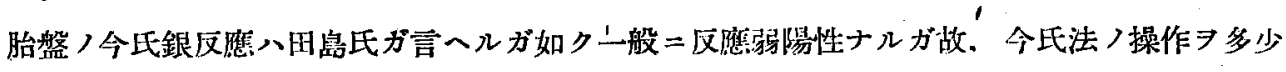

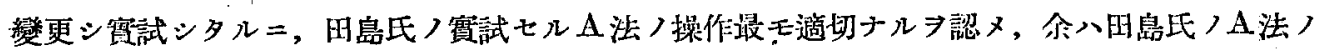

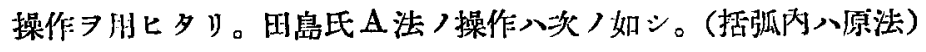

1) 組織 $フ 2-3$ 䊗つ薄片トナス。

2) $2 \% 「 ア ン モ=ヤ 」$ 性硝酸鍉溶液二投ジ 37 度孵卵器中 $=3$ 日間(24時間)放置ス。

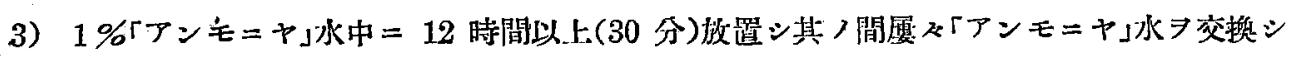


テ組織中ノ遊離銀液ノ脫出

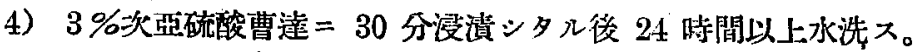

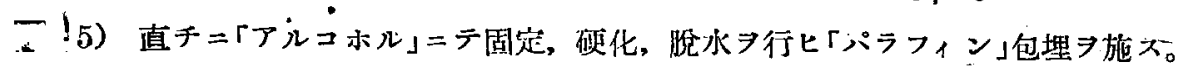

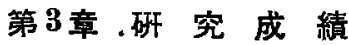

第 1 表二示ス如ク・66 例 姃娠各特期二於ケル胎盤ノ今氏銀反應 7 檢シタリ。

第 1 表

子宮內脱，今氏銀反脽:

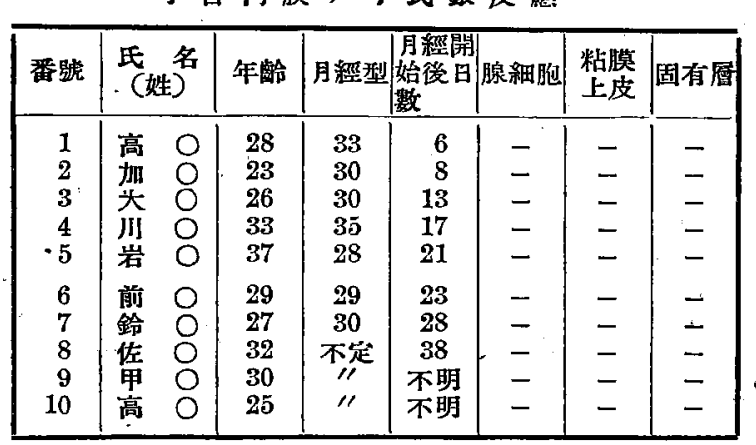

奥又第 2 表二示ス如ク 10 例 非妊子 腺內膜 /今氏銀反應 $\ni$ 試ミタルニ，粘膜 上皮及ビ腺紬胞八今氏銀反應螕テ险性= 終り，父圆有屏二於テモ今氏銀反應㓌性 タ示シタり。郎チ之等子宫內膜ノ請要素 八性音期ノ如何二カ、ワラズ, 褐染スル ノミニシテ黑褐色 $ヨ$ 呈スル今氏銀顆粒八 殆ド發見セズ。（第 1 表參照）

然ル $=$ 人胎盤 $=$ 於デハ今氏銀反應陽珄 ニシテ妊娠各時期二應ジ夫ぬ今氏銀顆粒ノ發現 7 見タリ。節チ 66 例ノ妊娠各時期二就イテ各 々略述スレバ头ノ如シ。(第 2 表參照)

第 2 表人胎盤, 今氏銀反临

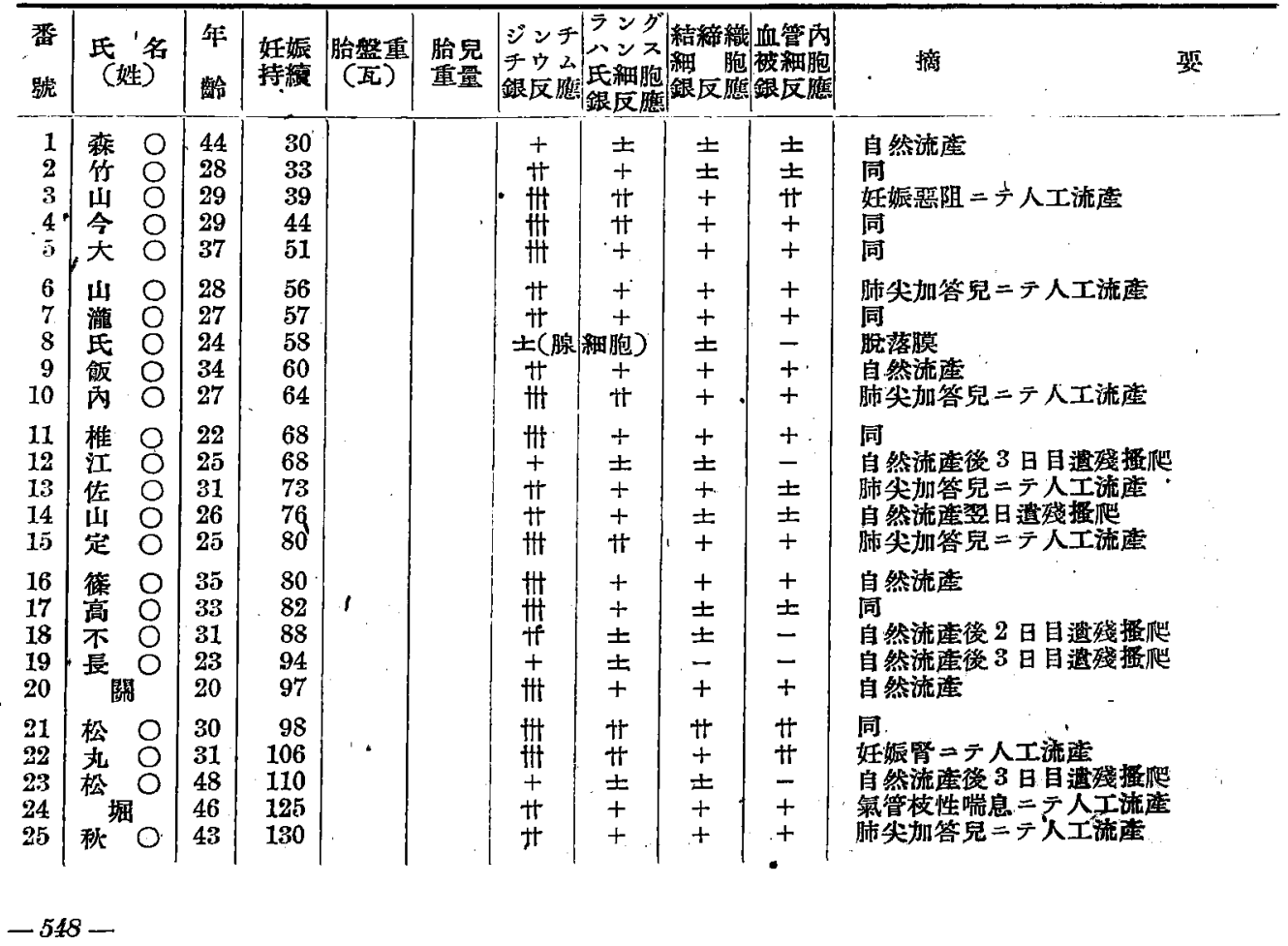




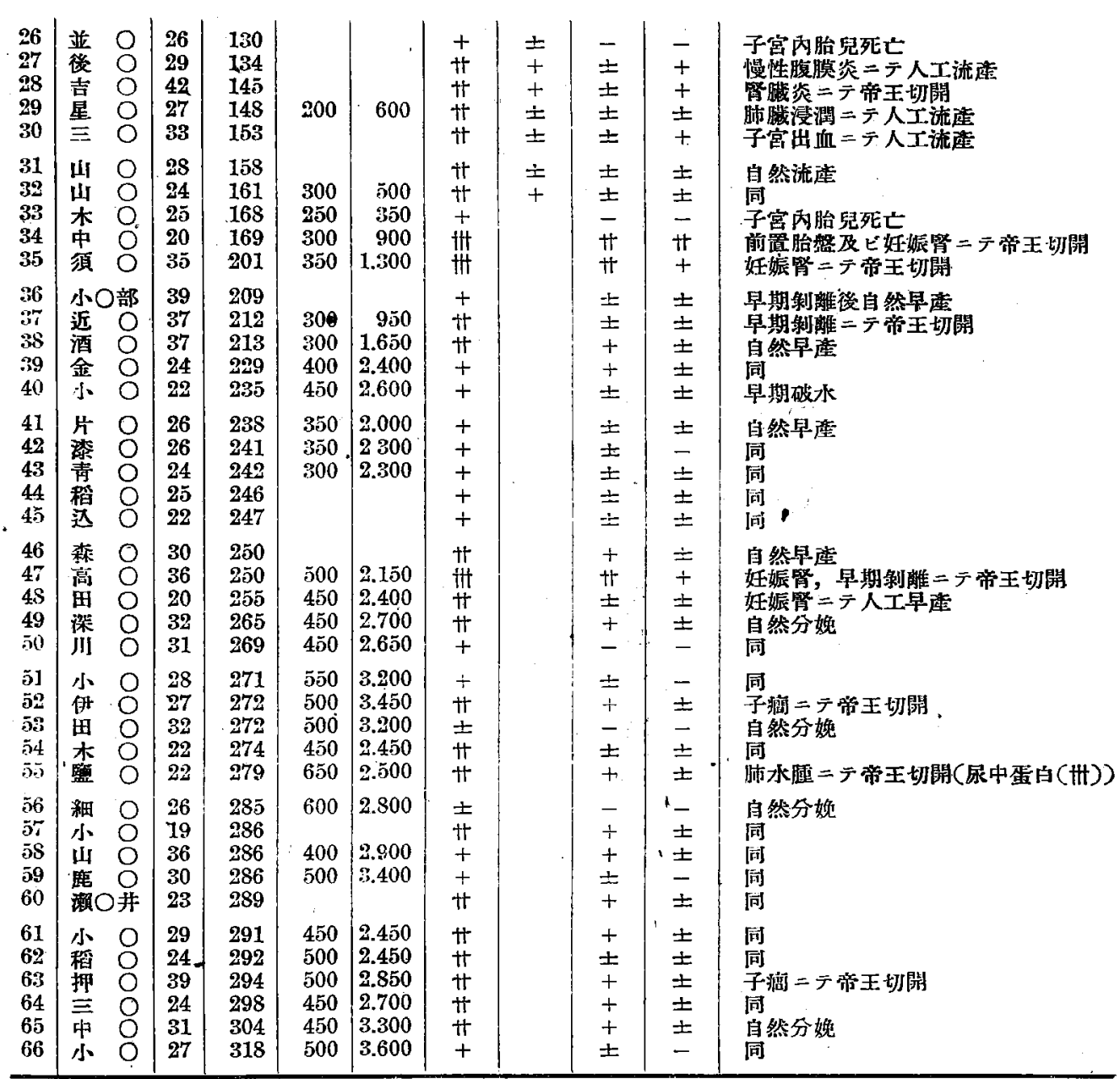

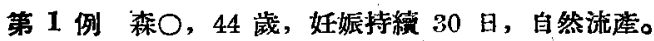

「ジンチチウム」細胞二稍々黑色味 $タ$ 有スル褐色ノ極メテ微細ナル顆粒トシテ, 主トシテ核周二 $($ 十)程庭二

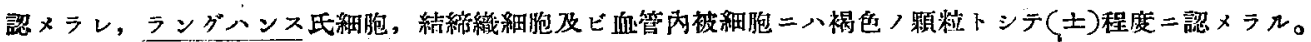

第 2 例 竹內, 23 歳, 弤娠持䌂 30 日, 自然流座。

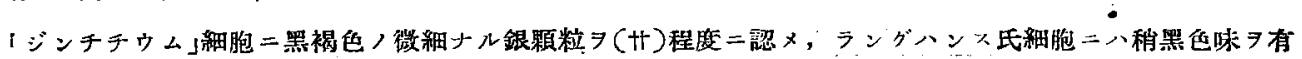

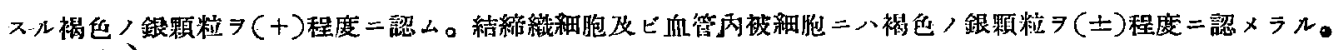

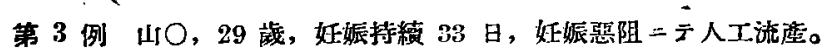

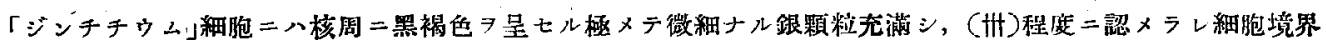

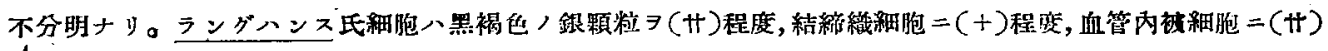

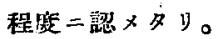

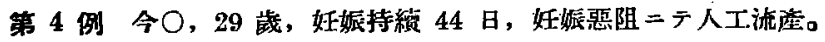

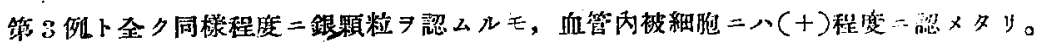




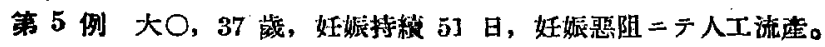

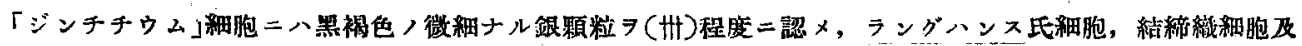
ビ血管內被細胞二八(十)程度二認メタリ・

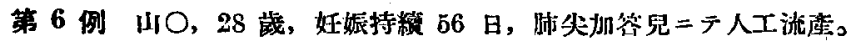

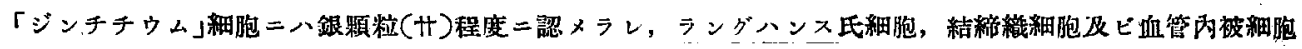
ニ八(十)程度二㑇メラレタリ。

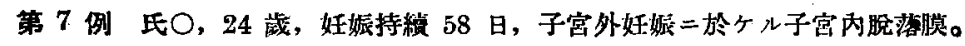

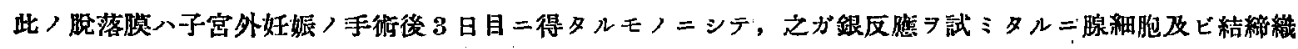
稩胞二八褐色，銀顆粒トシテ (士)程度二認メ，血管丙被細胞二八銀顆粒

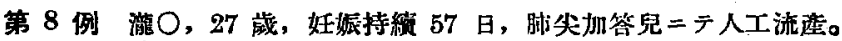

「ジンチチゥム」細胞二八銀制粒(サ)程度二認メラレ, ラングハンス氏細胞, 結䋨織細胞及ビ血管丙被細胞

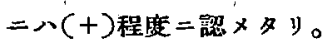

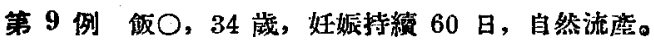

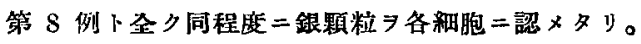

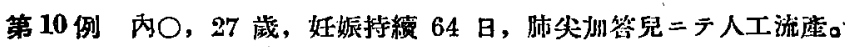

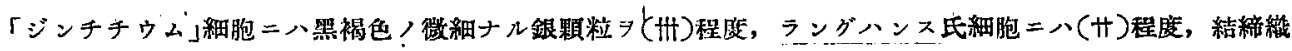
稩胞及ビ血管內被粨胞二八(十)程度二認メタリ。

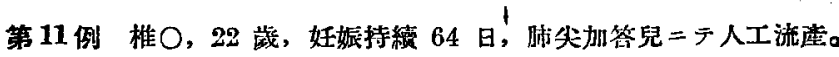

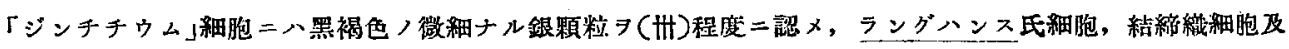
ピ血管內被細胞二八稍々黑味

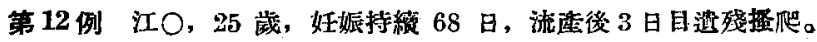

「ジンチチウム」細胞二八稍々黑味ラ帶ビタル褐他ノ比校的粗大ナル銀顆粒

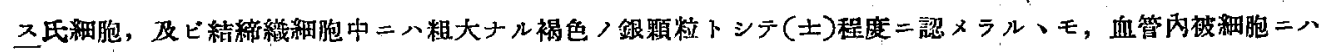
銀顆粒認メラレズ。

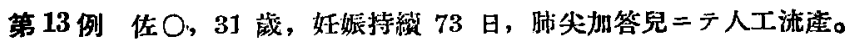

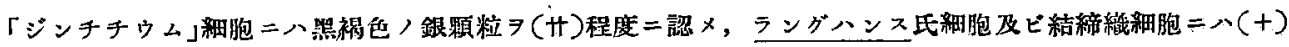
程度二衿メタリ。血管內被細胞二八褐色，銀顆粒卜シラ(士)程度二認メラル。

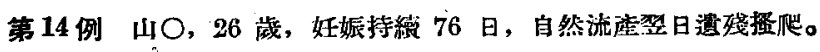

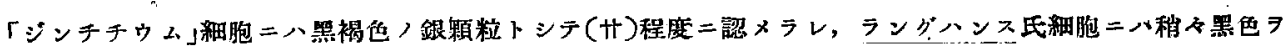

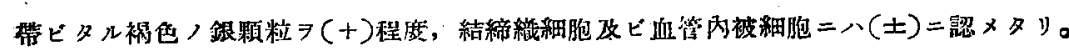

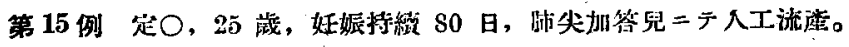

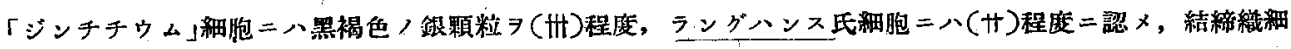

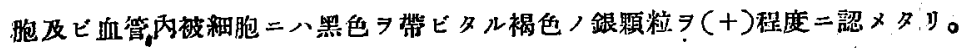

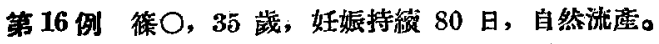

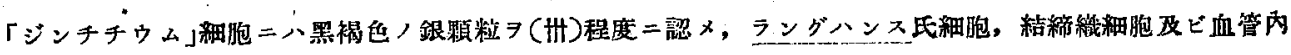

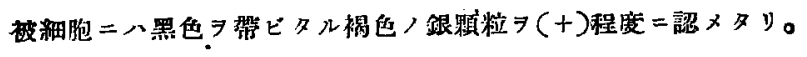




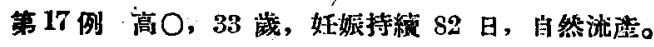

「ジンチウム」細胞二八照褐色〉銀顆料

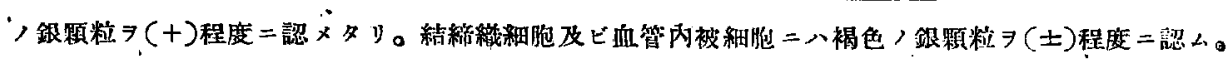

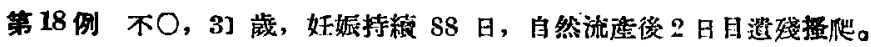

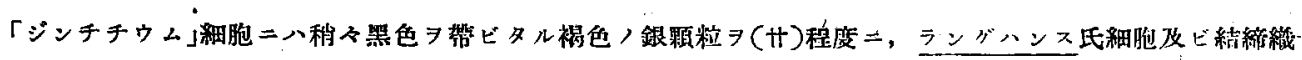

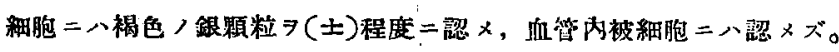

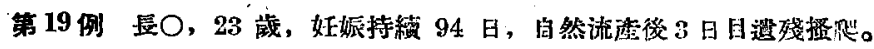

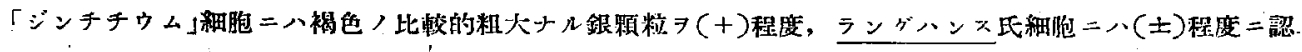
メ, 結締織細胞及ビ血管內被細胞二ハ認メラレズ。

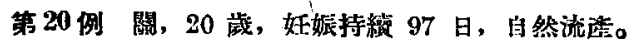

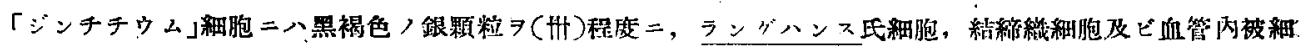
胞ニハ(十)程度 $ヨ$ 稍々著明二認メタリ。

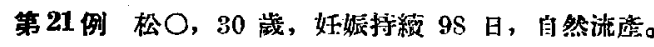

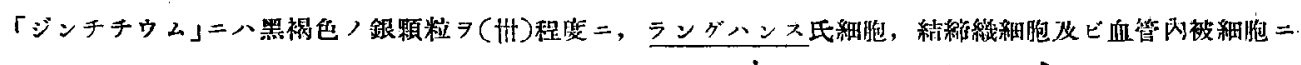
八(t十)程度二哂 $\times$ タ

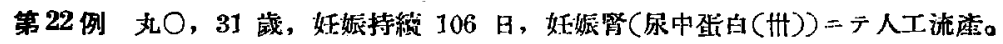

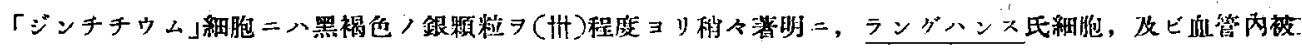
細胞二八(t)程度, 結締織細胞二八(十)程度以上二認 $\times タ y 。$

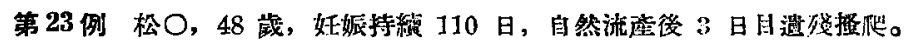

「ジンチチウム」細胞二八褐色ノ粗大ナル銀頖粒ヨ(十) 程度二, ラングハンス氏細胞及ビ結締䋨細胞二八 (土)程度二認メラル、モ，血管内被細胞二八認メラレズ。

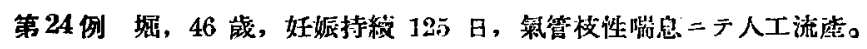

「ジンチチウム」細胞二八黑褐色ノ銀顀粒 及ビ血管內被細胞二メ(十)程庭二㜔メタり。

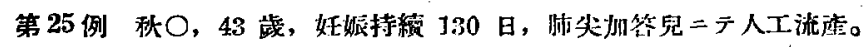

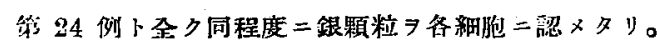

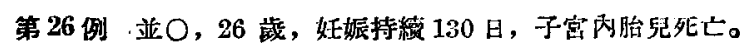

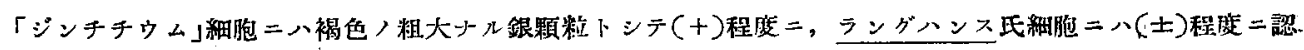
メタルモ, 結滴織細胞及ピ血管內被細胞二八認メラレズ。

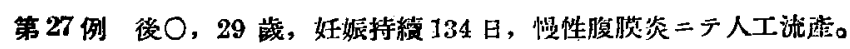

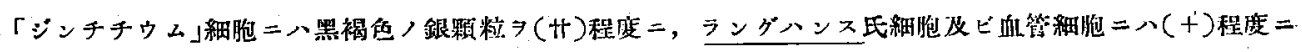

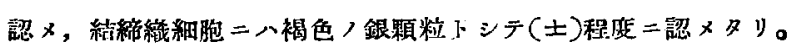

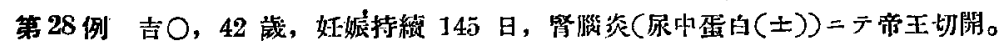

乘 27 例卜全方同程度二银顆粒 $\Rightarrow$ 各䄄胞二認么。

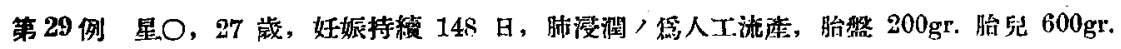




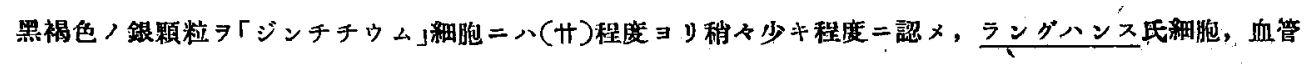

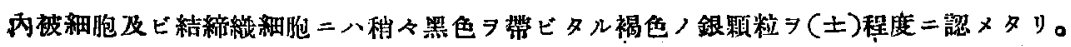

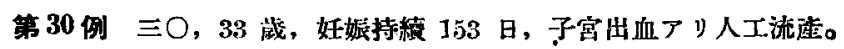

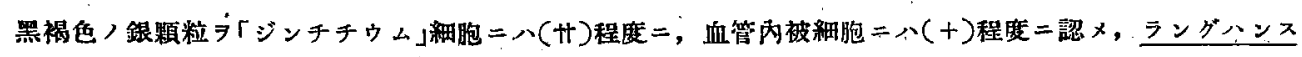

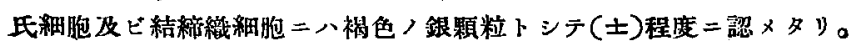

第 31 例 山O，28 歳，妊娠持續，158 日，自然流造。

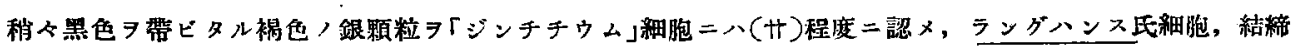

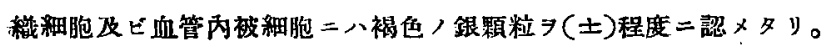

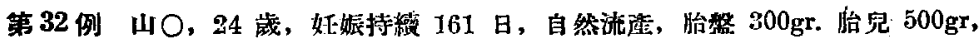

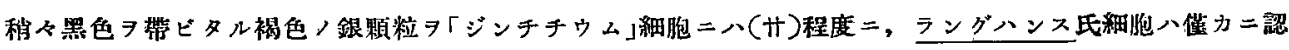

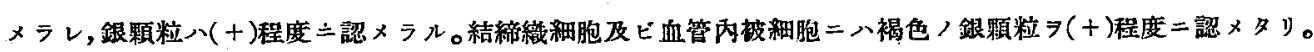

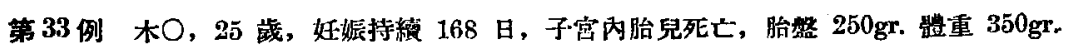

胎盤組織壦疽二落入ラザル部ニ於テ八粗大ナル褐色ノ銀顆粒トシテ「ジンチチウム」細胞ニ認メラレ, 結織 䄳湅胞及ビ血管內被細胞二八認メラレズ。ラングハンス氏細胞八認メラレズ。

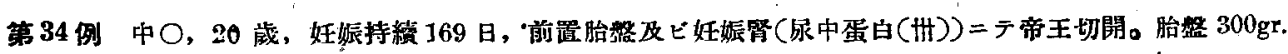
鰿重 $900 \mathrm{gr}$.

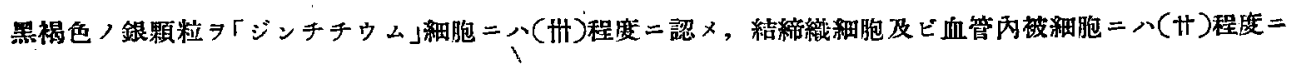
認メタリ。

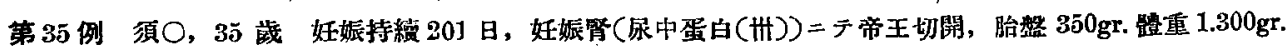

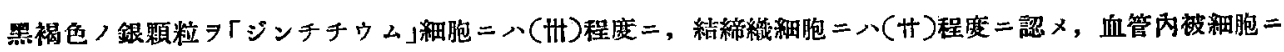
八稍み黑味ヨ帶ビダ褐色ノ銀顆粒ヨ認メタリ。

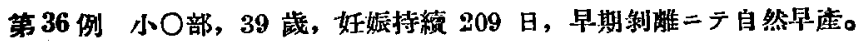

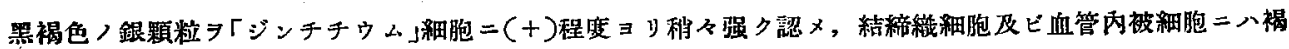
色 銀顆粒 $7( \pm)$ 程度二認メタリ。

第 37 例 近 $\bigcirc, 37$ 葴, 姡娠持緮 212 日, 早期制離二テ帝王切開。胎盤 $300 \mathrm{gr}$. 胎兒重量 $950 \mathrm{gr}$.

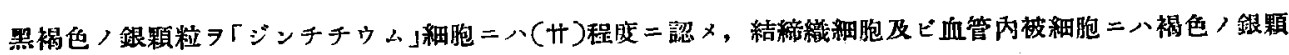
粒 $\ni( \pm)$ 程度二融メタリ。

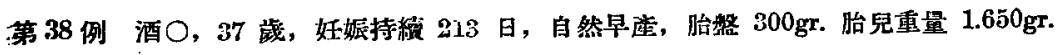

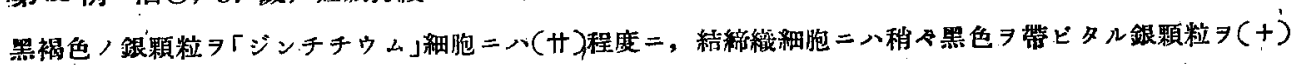
程度, 血管內被細胞二八䘽色ノ銀制粒 $ヨ( \pm)$ 程度二認メタリ。

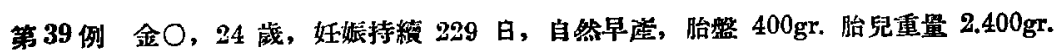

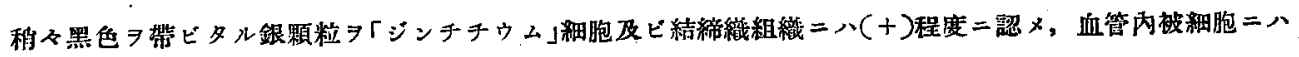
褐色 八 銀顆粒 $\exists( \pm)$ 程度二認么。

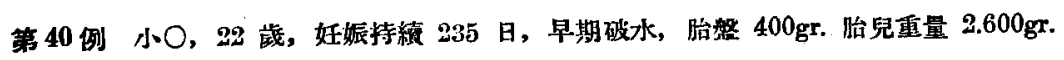

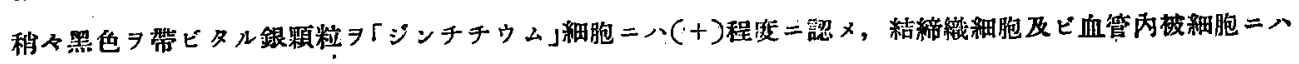
$-502-$ 
裸色ノ很顆粒 ジ(士)程度二認メタリ。

苐 41 例 片O，26 歳，妊娠持維 238 日，自然早店，胎盤 $350 \mathrm{gr}$. 胎兒重量 $2.000 \mathrm{gr}$.

銀顆粒八第 40 例卜金夕同程度二認メタリ。

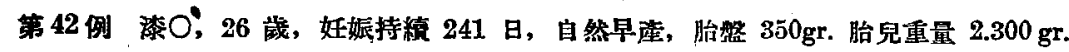

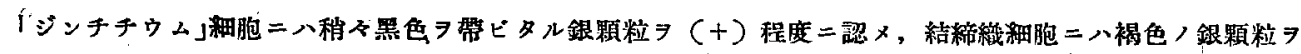
(士)程度二認メルモ，血管內被箱胞二八認メラレズ。

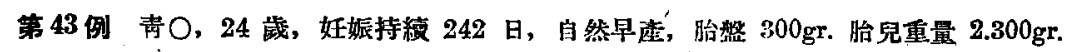

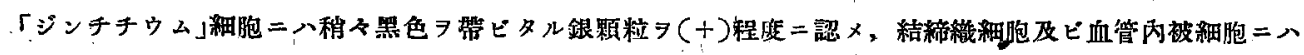
褐色ノ銀顆粒 $\exists( \pm)$ 程度二証メタリ。

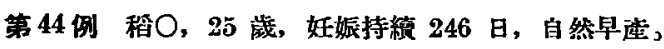

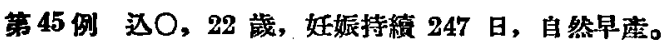

銀顆粒雨例卜モ第 43 例ト全ク同程度二認メラルルモ，第 43 例ノ「ジンチチウム」細胞二於ケル銀顆粒八 稍ふ其程度强キ

第 46 例 森 $\mathrm{O}, 30$ 歳, 妊娠持續 250 日, 自然早虚。

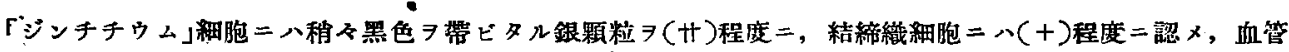
丙披細胞二八褐色 銀顆粒 $尹( \pm)$ 程度二認×タリ。

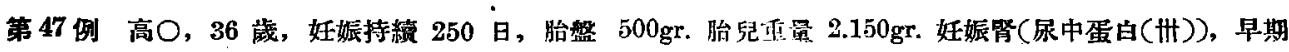
剩離二テ帝王切開。

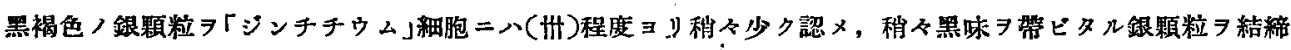
織細胞 $=(甘)$ 程度, 血管內被細胞 $=(+)$ 程度 $=$ 認 $\times$ タ》。

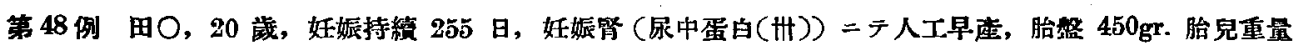

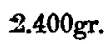

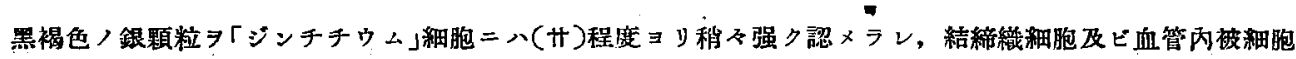
ニ八稍々黑味ヨ带ビタル銀顆粒 $ヨ( \pm)$ 程度二認么。

第 49 例 深O，32 歳，妊娠持縵 265 日，自然分始，胎盤 $450 \mathrm{gr}$. 胎兒重量 $2.700 \mathrm{gr}$.

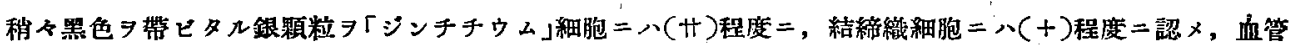
丙被細胞二八褐色ノ銀顆粒 $\exists( \pm)$ 程度二証メタy。

第 50 例 $川 O, 31$ 歳, 妊娠持綾 269 日, 自然分娩, 胎然 $450 \mathrm{gr}$. 胎兒重量 $2.650 \mathrm{gr}$.

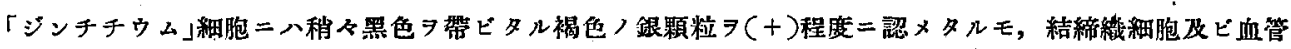
內被細胞ニハ認メラレブ。

第51例 小O，28 歳，妊娠持䌀 271 日，自然分娩，胎盤 $550 \mathrm{gr}$. 胎兒重量 $3.200 \mathrm{gr}$.

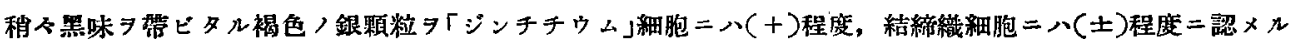
モ, 血管内被細胞二八認メラレズ。

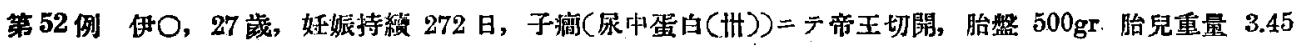
Ogr. 黑褐色 呈セル銀顆粒ヨ「ジンチチウム」細胞ニ八(サ)程度ヨリ稍强ク認メ、稍々黑味 
粒 $\rightrightarrows$ 結綰織細胞二八(十)程度, 血管內被細胕二八(士)程度二認メタリ。

第 53 例 由于, 32 歲, 妊娠持縝 272 日, 自然分婏, 胎盘 $500 \mathrm{gr}$. 胎胃重量 $3.200 \mathrm{gr}$.

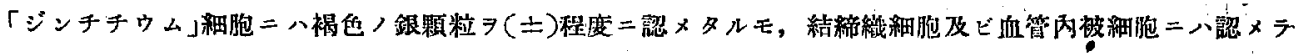
UR゙。

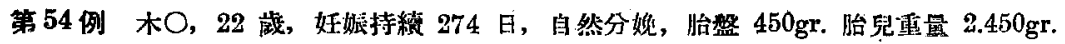

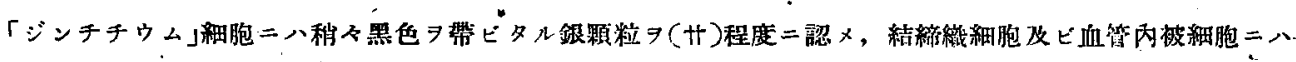
䶂色ノ銀顆粒 $\rightarrow( \pm)$ 程度二認メタリ。

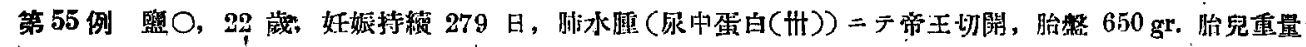
$2 . \stackrel{1}{5} 00 \mathrm{gr}$.

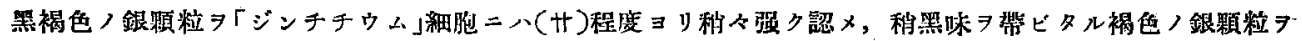
䊅綝織細胞 $=(+)$ 程度, 血管內被稩胞二(士)程度二認メタリ。

第 56 例 細O，26 蒇，妊娠持楛 285 日，自然分娩，胎艋 600gr. 胎兒重量 $2.800 \mathrm{gr}$.

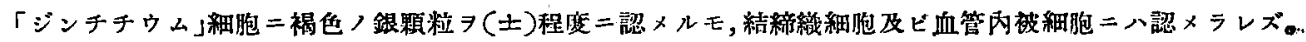
第57例 小○, 19 歳, 弤娠持綂 286 日, 自然行婏。

稍々黑味 $シ$ 帶ビタル褐色ノ銀顆粒 二八(十)程度，血管内被細胞二八(士)程度二認メタリ。

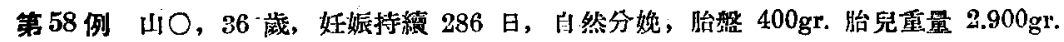

銀顆粒第 57 例ト全ク同程度二备稩胞二認メラル。

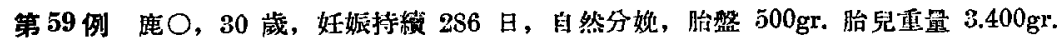

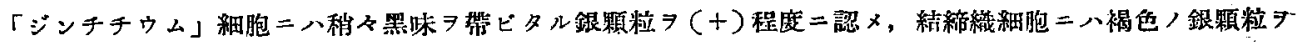
(士)程度二認メシモ, 血管內被程脽中二ハ認メラレズ。

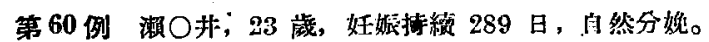

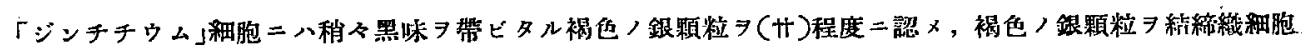
二八(十)程度, 血管丙被細胞二八(土)程庭二認メタリ。

第 61 例 小 0,29 歳，妊脈持綕 291 日，自然分始，胎盤 $450 \mathrm{gr}$. 胎兒重量 $2.450 \mathrm{gr}$.

銀顆粒第 60 例卜全ク局程度二各細胞トモ認メタリ。

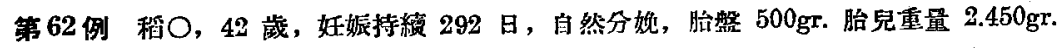

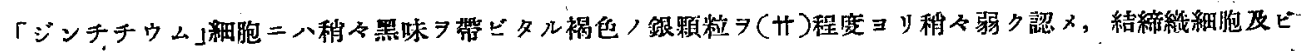

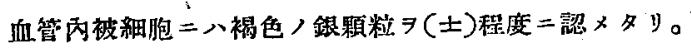

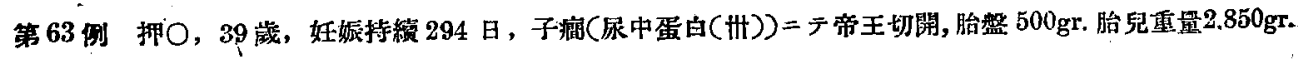

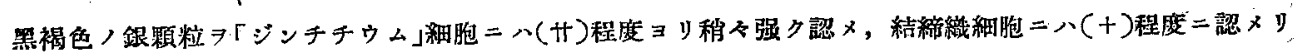
血管內被勫胞二八襡色 $/$ 銀顆粒 $\exists( \pm)$ 程度二認メタリ。

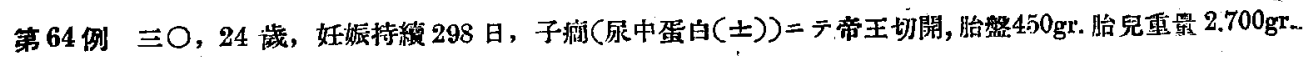
银顆粒第 63 例卜全ク同程度二各細胞ト七認メタリ。

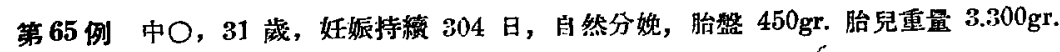




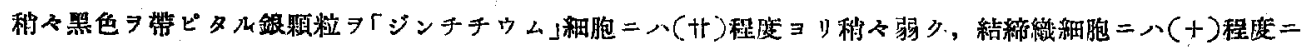

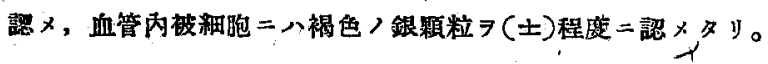

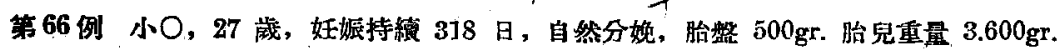

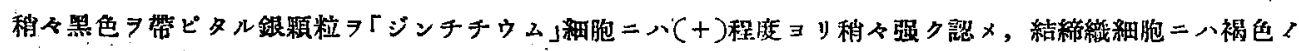
銀颗粒 $\exists( \pm)$ 程度二認 $\times$ タルモ，血管內被細胞二八認メラレズ。

\section{盷狀鬼眙 /今氏銀反應}

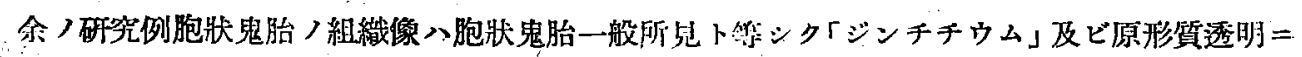
シテ，比較的大ナル細胞核ヨ有スル所謂ランダハンス比細胞ョリナリ，二厤トモ增殖ヨ柫シ，

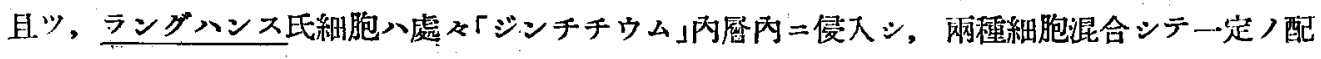

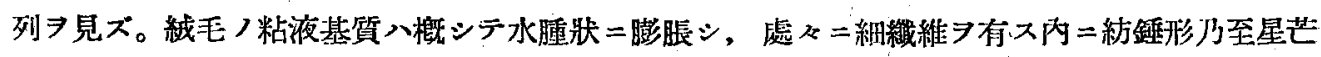
状ノ結締織細胞散在スル メ, 中央部入無構造物質ヨリナル。

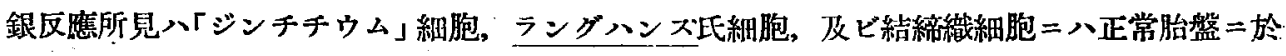
ケルト殆ド同樣ナル黑褐色ノ銀顆粒發現シ「゙ジンチチウム」細胞ノ銀反應八正常胎盤二比シ强 陽性ナリ。

第 1 例 糟○, 29 砧, 䛦断, 胞狀鬼胎。

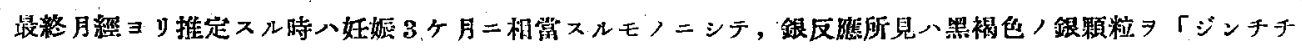

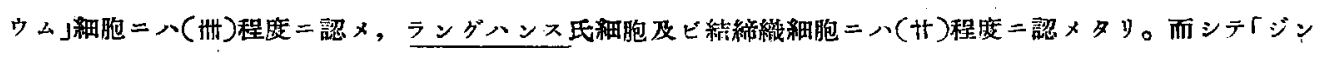
チテウム」細胞ノ銀顆粒八微細ニシテ其細胞境界八不分明ナ゙リ。

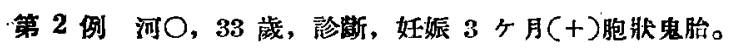

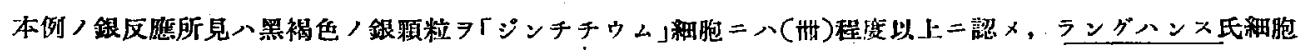
及ビ結䋨蟣䋑胞二八(卅)程度二認メラル。

第 3 例 三O, 26 歲, 椡, 胞狀鬼胎。

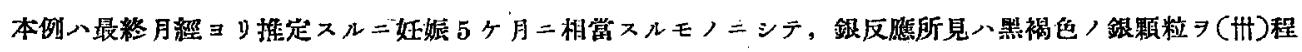

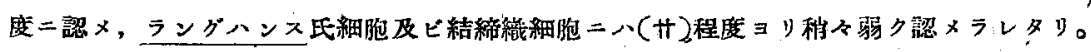

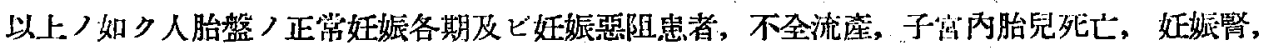

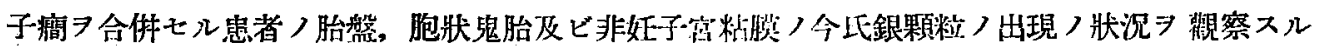

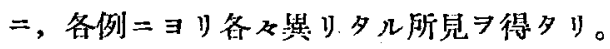

\section{第 4 章 總 括}

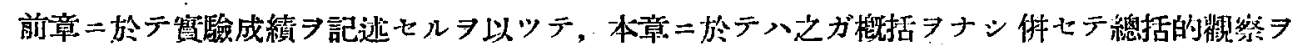
試ントス。

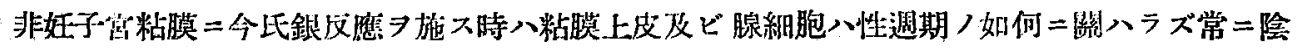

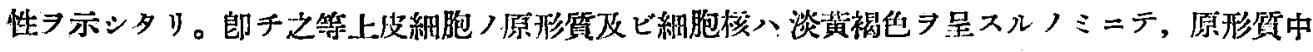

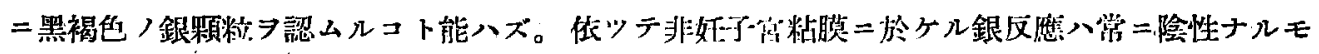




\section{ノトス。}

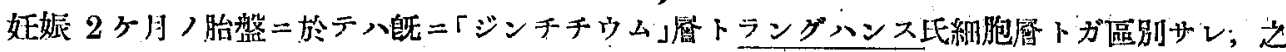

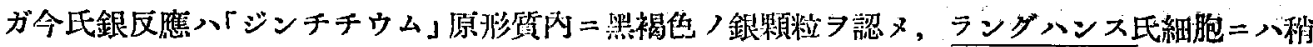
ズ黑味ヨ帶ビタル褐色ノ銀顆粒フ認メタリ。然シ娃娠惡阻タ合件セル胎盤ニ於イテハ「ジンヂ

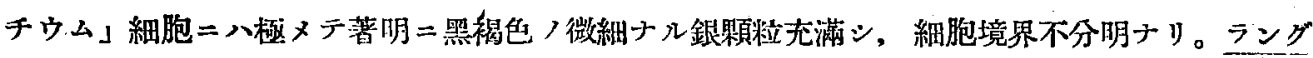

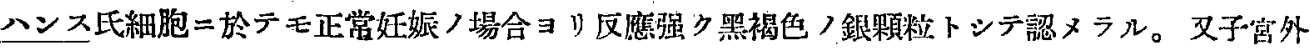

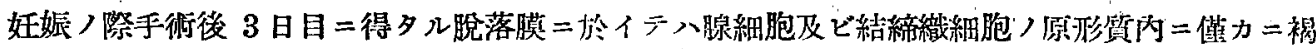
色ノ銀顆粹トシテ認メラレタリ。

娃㜊 3 ケ月/胎盤二於テハ「ジンチチウム」細胞及ビラングハンス氏細胞 /今氏銀反雇，正管

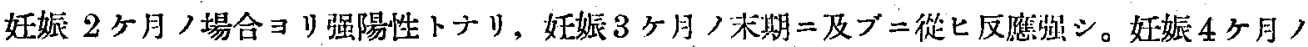
胎盤ノ今氏銀反應八好娠 3 ケ月末期卜全ク同程度二銀顆粒ヨ認メタリ。然シテ「ジンチチウム」 細胞，銀顆粒八微細ナ几黑裀色）銀顆粒ニシテ，テンダハシス氏細胞二現ハル顆粒ハ「ジンチ

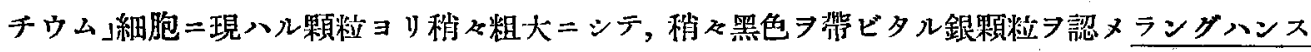
氏細胞ニ゙於ヶル銀反雇ハ「ジンチチウム」細胞二比シ遥カニ弱陽性ナリ。妊娠 3,4 ケ月ニ゙テ自然 流產後遣產搔爬 $ヨ$ 行ヒテ得タル胎盤〉銀反應八, 正常弤娠二比シ秒飞銀反應弱陽性ニシテ, 流

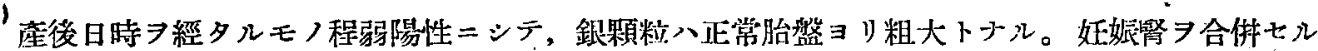
妊娠 4 5月八胎盤ノ銀反應八正常胎盤二此稍仗銀反應强シ。

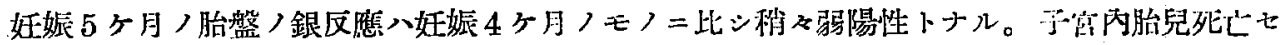

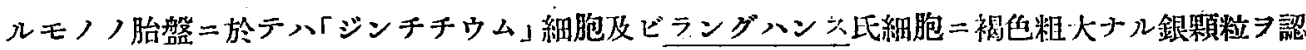
メ, 其反應正常胎盤二此シ遥カニ弱シ。

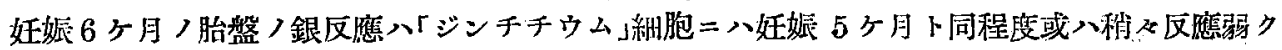

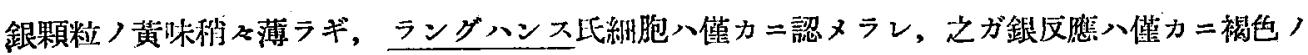

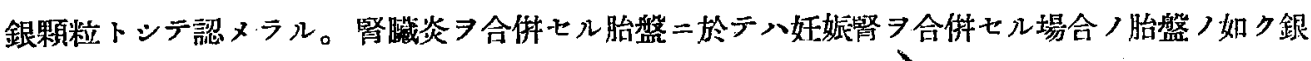
反應强陽性 7 号セズ，正常胎盤卜同程度つ銀顆秥:認メタり。

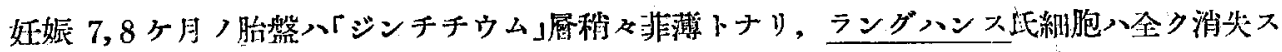

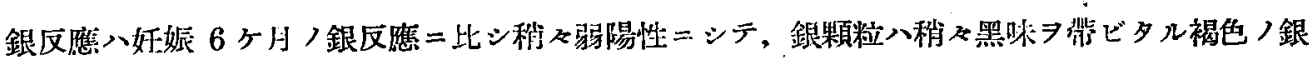

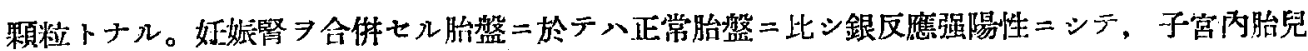

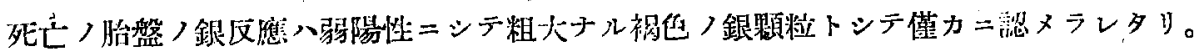

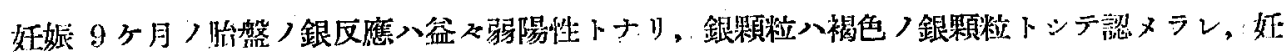

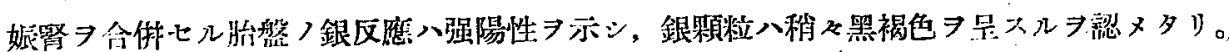

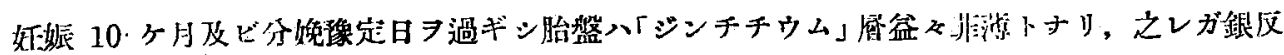

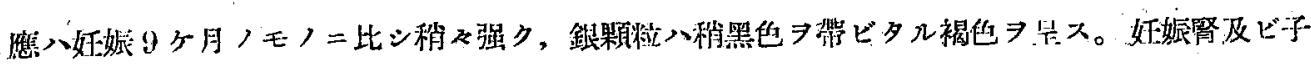

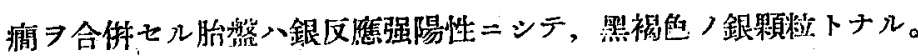




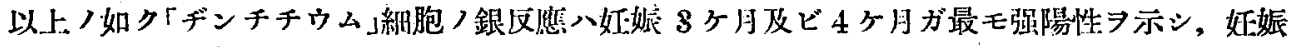

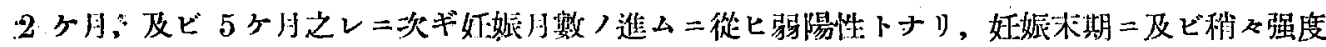

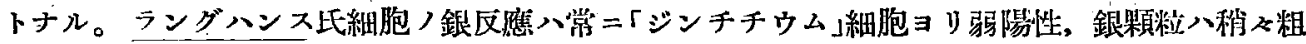
大ニシテ，妊娠 3 ケ月及ビ 4 ケ月ガ强陽性フ示シ，妊脄 2 ケ月，5 ケ月，6 ケ月ノ胎盤二於テ 八減弱入。胎盤結締織細胞及ビ血管內被細胞, 銀反應入前二者二比シ，弱陽性ニシテ，「ジンチ チナム」細胞二現ハルル銀反應二比例シテ强弱 $゙$ 呈ス。

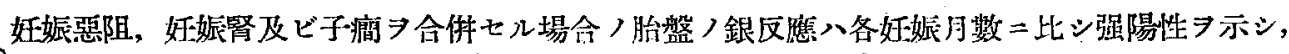

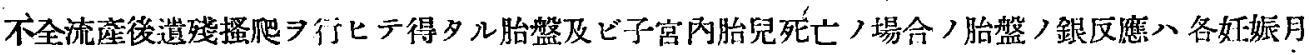
數二比シ反應搦陽性ニニシテ銀顆粒入稍々粗大ナリ。

田息氏ノ家鬼胎盤二於らル「ジンチチウム」八妊娠 3 週前後郎チ弤娠持續 $3 / 4=$ 於テ銀反應

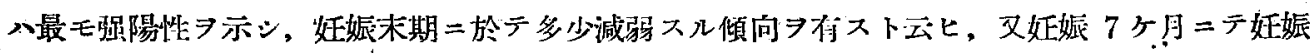

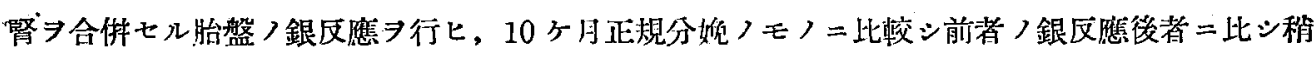

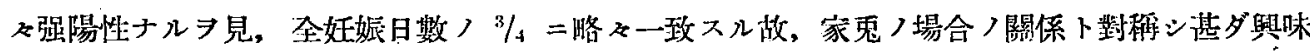
アルモ合伴症アル故正鵠ヨ期シ難シト云つ。余ノ人胎盤ニ於ケル「ジンチチウム」細胞つ銀反應 八好娠 3 ケ月及ビ 4 ケ月が最モ强陽性 示シ，奸娠月數つ進ム二從ヒ多少減弱スルモ，奸娠本期二稍飞区應强度トナル點多少相違つリ。

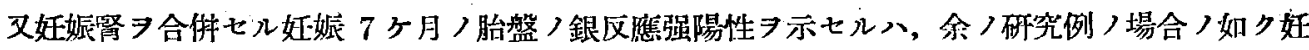

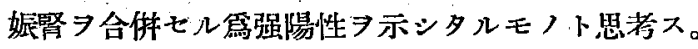

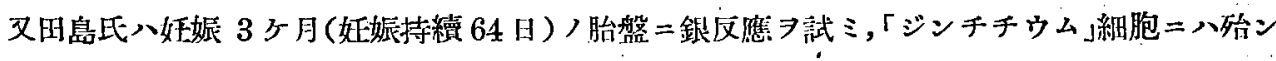

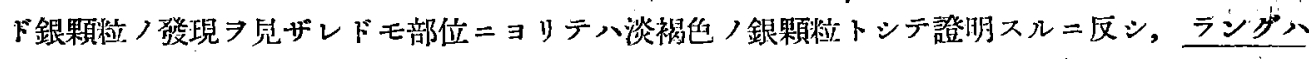

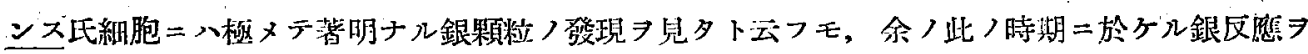

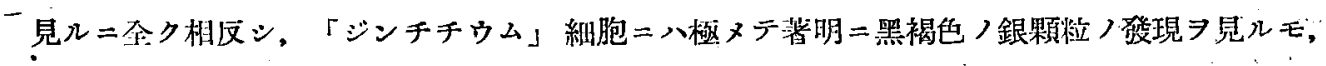

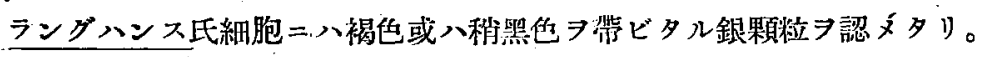

少又胞狀鬼胎ノ銀反應二就テ时島氏ハ「ジンチチウム」繧胞二八正常胎盤二於ケルト㱠ド同様

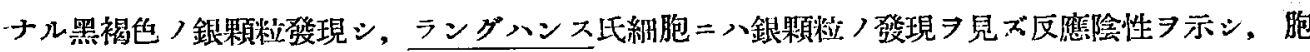

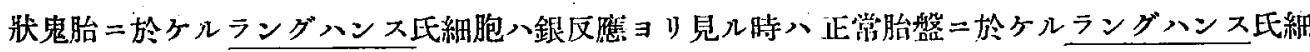

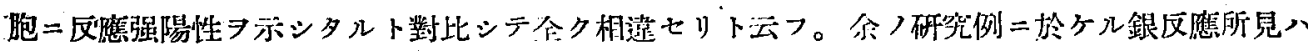

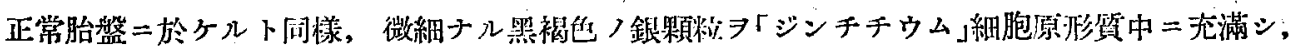

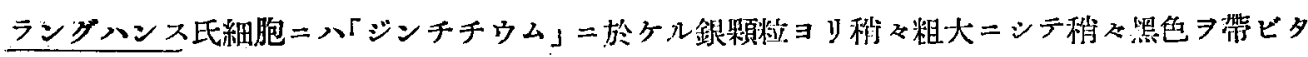

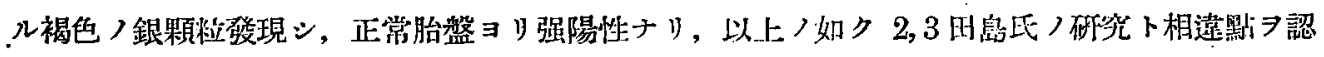
メタリ:

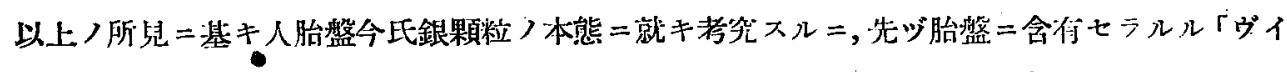
タミン」C及ビ胎盤「ホルモン」トノ閵係习結定セネバナラヌ。「ヴイタミン」C＝就テ八阔本氏， 
妊娠各月胎盤中「ヴイタミン」C舍量ヨ兒ルニ第3ろ月ノモノ郎チ胎盤完成前ニ於デ、極メテ低值

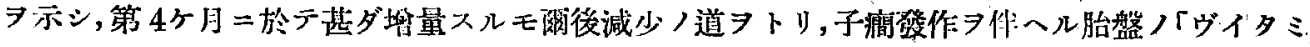

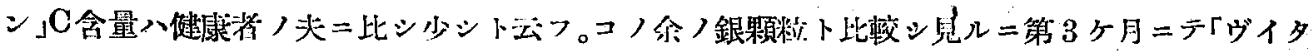

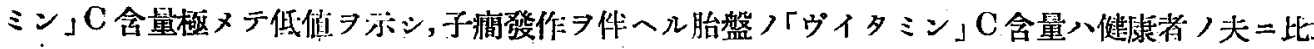

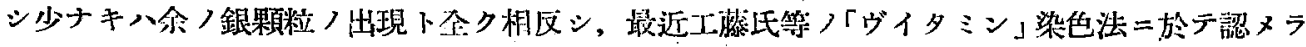

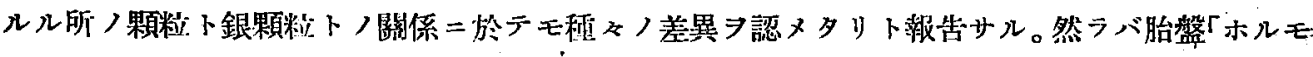

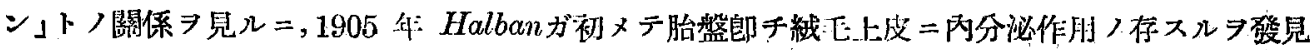

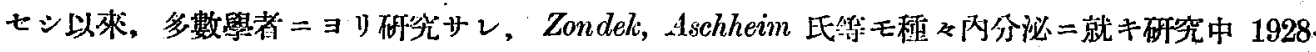

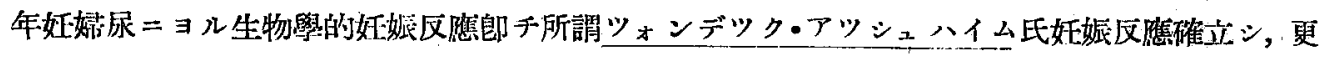

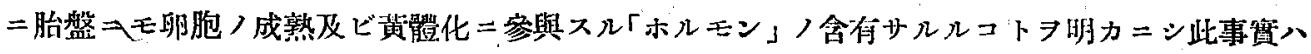

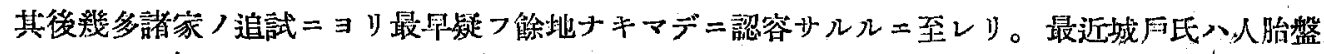

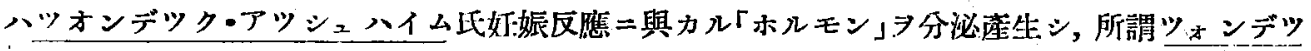
ク・ア゚ッシュハイム氏弤娠区隼八腦下垂體前葉「ホルモン」ト胎盤「ホルモン」（トロホブラスト・ ホルモン）トガ同時二協力作湖スルコトニヨリ始メテ成立スルモノナリト云フ。

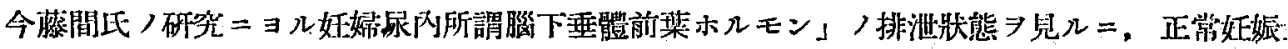

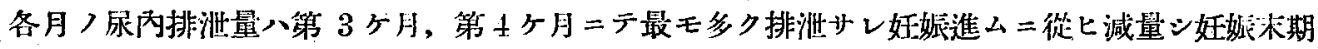

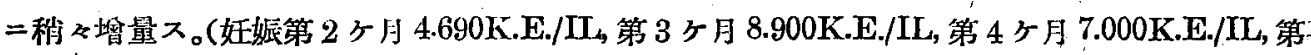
5 ヶ月 $4750 \mathrm{~K} . \mathrm{E} . / \mathrm{\Pi L}$, 第 6 ケ月 $3.350 \mathrm{~K} . \mathrm{E} . / \mathrm{IL}$, 第 て ケ月 $2.600 \mathrm{~K} . \mathrm{E} . / \mathrm{\Pi}$, 第 8 ケ月 $2.700 \mathrm{~K} . \mathrm{E} . / \mathrm{IL}$, 第

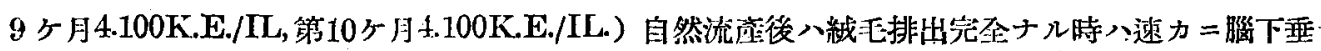

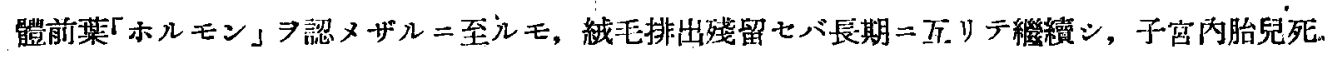

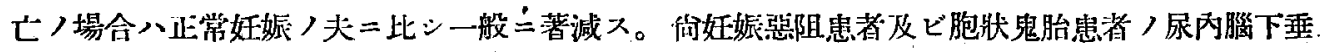

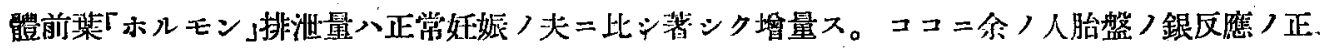

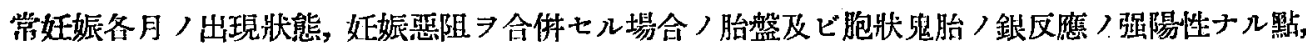

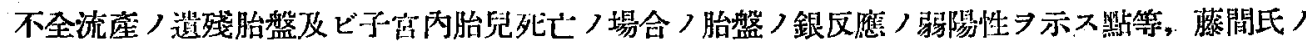

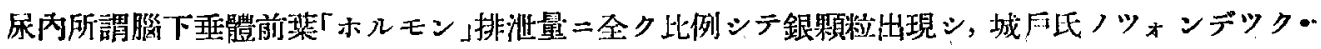
アッシュハイム氏弤娠反㗹八腦下垂體「ホルモン」ト胎盤「ホルモン」トガ同時二協力作用スルコ

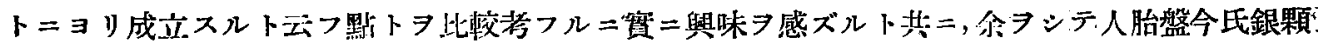

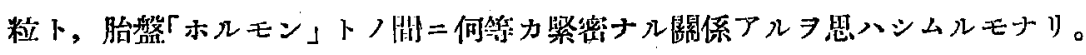

\section{第 5 章 結 論}

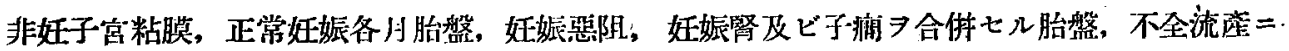

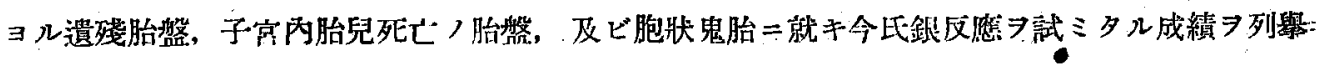
セバ头ノ如シ。 


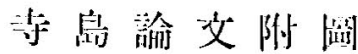
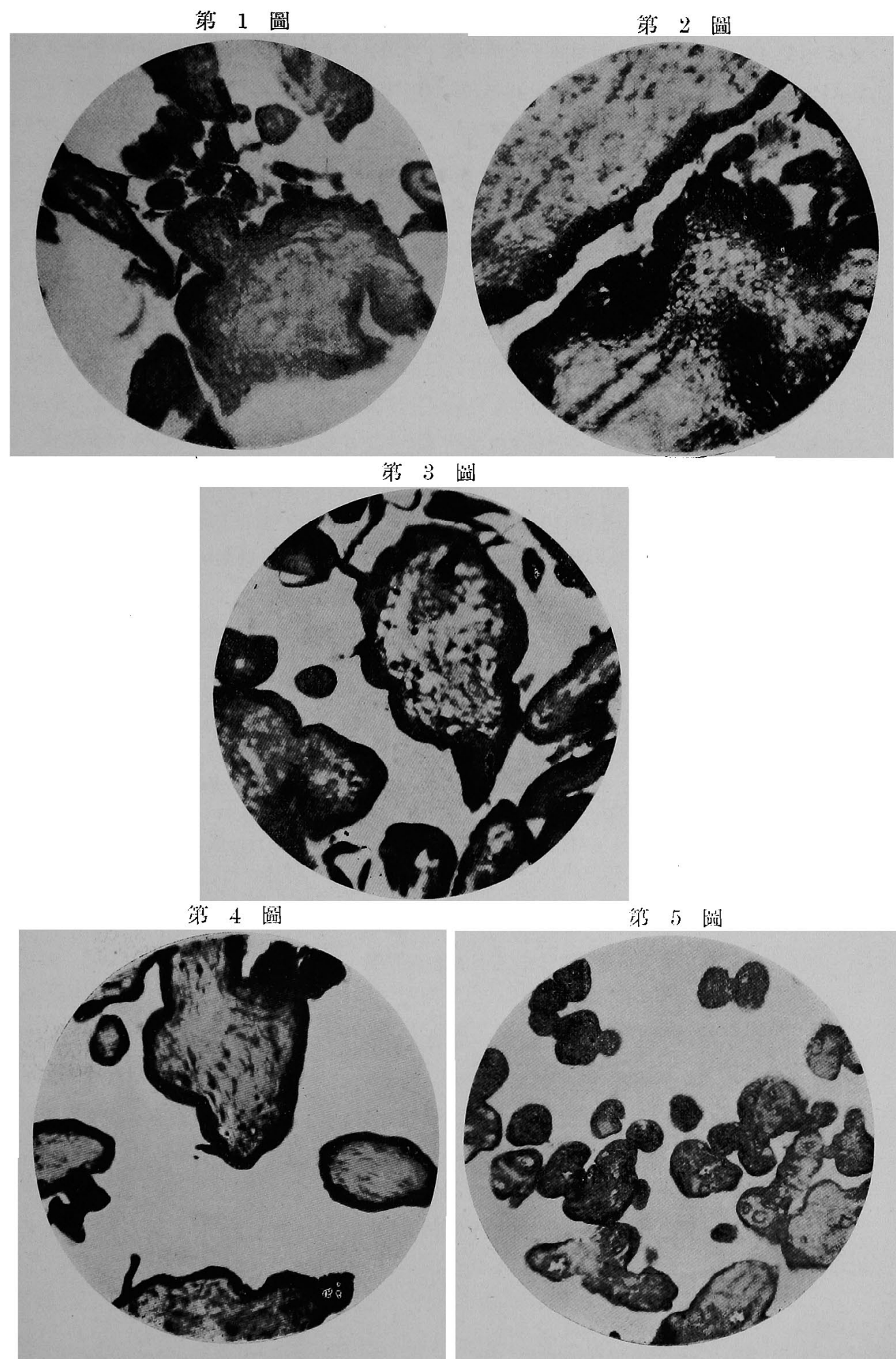


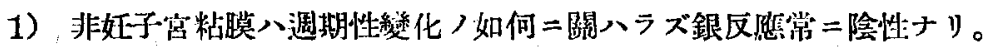

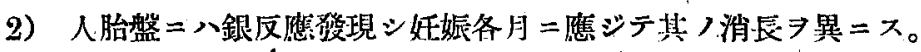

3）人胎盤「ジンチチウム」細胞二於らル銀反應八妊娠 3 ケ月，45月最モ强陽性ニシテ，妊

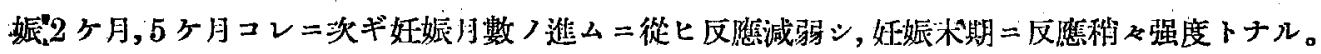

4）人胎盤シングハンス氏細胞，銀反應ハ常ニ「ジンチチウム」細胞ヨリ弱陽性ニシテ，弤娠，

3 ケ月，4 ケ月ガ强陽性ナルモ娃娠 2 ケ月，5ケ月，6 ケ月二テハ減弱ス。

5）胎盤ノ毛細血管內被細胞及ビ結締織細胞 銀区應六弱陽性:ニシテ「ジンチチウム」細胞ノ 消長二比例シ增隇スルガ如シ。

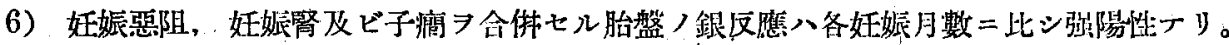

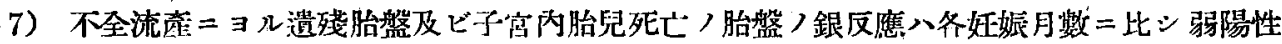
ナリ。

8）胞狀鬼胎フ「ジンチチウム」絒胞及ビラングハンス代細胞二モ゙正常胎盤ニ於ケルト同樣ナ ル銀顆粘發現シ極メテ强陽性ナリ。

9）人胎盤今氏銀顆粘》胎盤「ホルモン」ト關係アルモノト思考入。

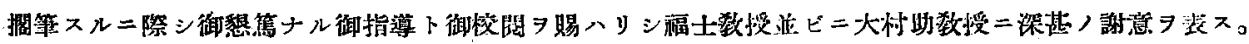

\section{主 要 文 獻}

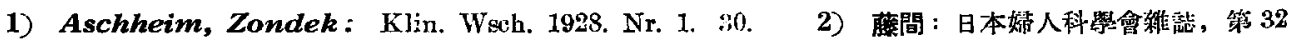
兊，第11號，第12號，昭和12年

3) G. Gaehtgens: Klin. Wsch. 1987. Nr. 31

4) 伊藤：北

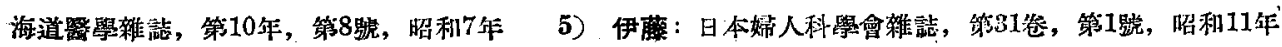

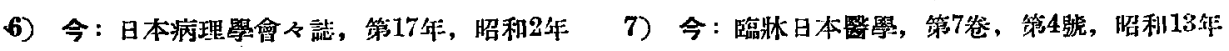

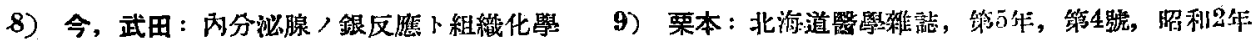

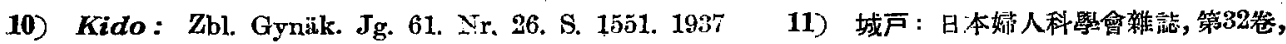

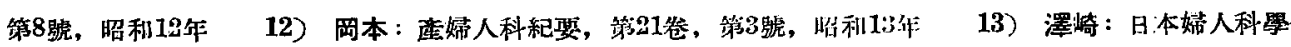

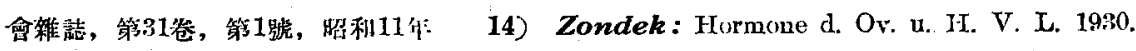

\section{附 圖 說 明}

第 1 圆 Nr. 2. 竹內 妊娠 25 月/ 自然流座例今銀区雇

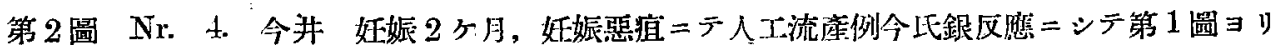
强陽性ナリ。

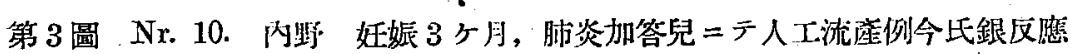

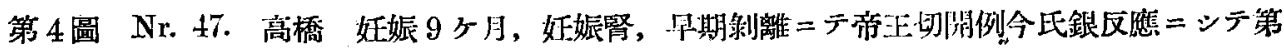

5 圖ヨリ遥カ二强陽性ナリ。

第 5 圖 Nr. 65. 中䟥 弤脄105月，自然分娩例令氏反應 